\title{
Partial excision of the nidus of an atypical cancellous osteoid osteoma by use of a bone marrow biopsy needle under fluoroscopic guidance
}

\section{Atipik kansellöz osteoid osteomada floroskopi kılavuzluğunda kemik iliği biyopsi iğnesi ile nidusun kısmi eksizyonu}

\author{
Ahmet Yilmaz ${ }^{1}$ \\ ${ }^{1}$ Deputy Surgeon-in-Chief, Department of Orthopedics and Traumatology, Adana City Training and Research Hospital, University of Health \\ Sciences, Adana, Turkey \\ * Corresponding author: Ahmet Yılmaz E-mail: ahmetyilmaz-dr@hotmail.com ORCID: 0000-0002-4015-5045 \\ Received: 28 November 2018 Accepted: 18 May 2019
}

\begin{abstract}
Aim: The widely accepted method in treatment of osteoid osteoma is either the complete excision or destruction of the nidus. The aim of this study was to evaluate the efficacy of partial nidus excision using a bone marrow biopsy needle as a minimally invasive technique for management of atypical cancellous osteoid osteomas.
\end{abstract}

Material and Method: Partial excision of the nidus was performed in four cases using an 11-G bone marrow biopsy needle under fluoroscopic guidance. The lesions were located in the capital femoral epiphysis, the posterosuperior side of the femoral neck, the distal tibial epiphysis and the olecranon process of the ulna.

Results: The patient's pain resolved the night following excision of the nidus. No recurrence was observed at the $72,36,32$ and 24 month follow-ups.

Conclusion: Partial excision of the nidus may be considered a remarkable technique especially in the treatment of atypical cancellous osteoid osteoma, where surgical intervention is challenging.

Keywords: osteoid osteoma, partial excision, fluoroscopy, biopsy needle 


\section{öz}

Amaç: Osteoid osteoma tedavisinde yaygın olarak kabul edilen yöntem nidusun ya tam eksizyonu ya da tahrib edilmesidir. Bu çalımanın amacı, atipik kansellöz osteoid osteoma tedavisinde minimal invasiv teknik olarak kemik iliği biyopsi iğnesi ile kısmi nidus eksizyonu etkinliğini değerlendirmekti.

Gereç ve Yöntem: Dört olguda 11-G kemik iliği biyopsi iğnesiyle floroskopi kılavuzluğunda nidusun kısmi eksizyonu uygulandı. Lezyonlar femur başı epifizi, femur boynu posterosüperior tarafı, tibia distal epifizi ve olekranon çıkıntıda yerleşmişlerdi.

Bulgular: Hastaların ağrısı nidus eksizyonunu takip eden gece geçti. 72, 36, 32 ve 24. aylardaki takipte nüks görülmedi.

Sonuç: Nidusun kısmi eksizyonu özellikle cerrahi girişimin zor olduğu atipik kansellöz osteoid osteoma tedavisinde dikkate değer bir teknik olarak düşünülebilir.

Anahtar kelimeler: osteoid osteoma, kısmi eksizyon, floroskopi, biyopsi iğnesi

\section{INTRODUCTION}

The Osteoid Osteoma (OO) is the third most common benign bone tumor, and is commonly seen in the second and third decades of life. The OO lesion was first proposed as a distinct entity by Jaffe in 1935 [1]. More than half of these lesions occur in the long bones of the lower extremities. The proximal femur, mainly in the neck portion, is the most frequent location for the development of an $\mathrm{OO}$ [2-4]. OO lesions can occur anywhere within the bone, including the cortex, medulla, subperiosteal and intracapsular areas. OO lesions are rarely seen in the epiphysis of the femur, the carpals, the phalanges, the bones of the pelvis and the vertebrae [5-10].

It has been accepted that a complete recovery from an $\mathrm{OO}$ is possible through the removal or destruction of the nidus. A residual nidus has been reported to be a source of recurrence [11]. In our study, we evaluated the efficacy of interventional partial nidus excision technique using a bone marrow biopsy needle under fluoroscopic guidance in patients with atypical cancellous bone OOs.

\section{MATERIAL AND METHOD}

Four patients with atypical cases of 00 underwent partial nidus excision under fluoroscopic guidance by an $11 \mathrm{G}$ bone marrow biopsy needle (11G Jamshidi bone marrow biopsy needle, CareFusion, San Diego, CA) at the Orthopedics Department of our training and research hospital between 2009 and 2016. Approval of the local ethics committee was obtained. Informed consent forms were signed by the patients or their parents. All patients presented to our clinic complaining of pain on their involved extremity. The patients' pain increased at night, and was relieved with salicylates or non-steroidal anti-inflammatory drugs. The average onset of pain was 5.8 months (range 2 to 14) before the intervention. Radiographic examinations were performed by obtaining AP and lateral X-ray views of the painful bones, which along with computed tomography (CT). In all cases we performed a partial excision of the nidus of the same lesion twice sequentially in the same session.

\section{Case 1}

Our first atypical 00 was in the left capital femoral epiphysis near the physeal line of an 8-year-old boy. The patient had been treated for Legg-Calve Perthes disease for a year at another hospital. The lesion had a sclerotic zone of approximately $2 \mathrm{~cm}$ with a partially discernible lucent focus on plain radiographs (Figure 1a). CT scans showed a welldelineated sclerotic area $17 \mathrm{~mm}$ in size with a central lytic focus of $5 \mathrm{~mm}$ (Figure 1 b). We performed an interventional procedure to excise a $1.5 \mathrm{~mm}$ portion of the nidus using an $11 \mathrm{G}$ Jamshidi biopsy needle under fluoroscopic guidance (Figure 1c). Histopathologic diagnosis confirmed that the lesion was an OO. CT scans at the one-year follow-up revealed that the nidus was calcified, and surrounded by a dense peripheral sclerosis (Figure 1d). Plain radiographs 72 months after intervention showed a complete resolution of the sclerosis, and the central lucency was not visible (Figure 1e). A repeat $\mathrm{CT}$ also demonstrated a calcified nidus with a diminished sclerotic area and excessive ossification of the femoral head (Figure 1f). 


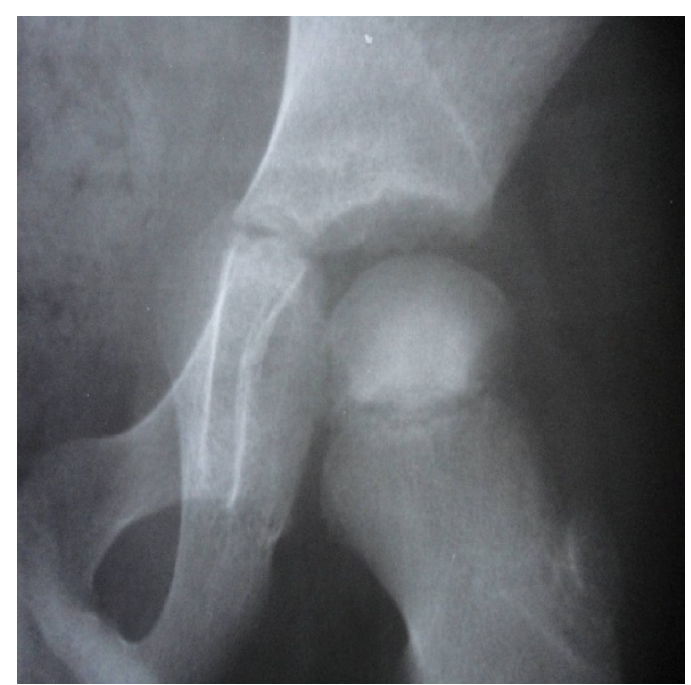

(a)

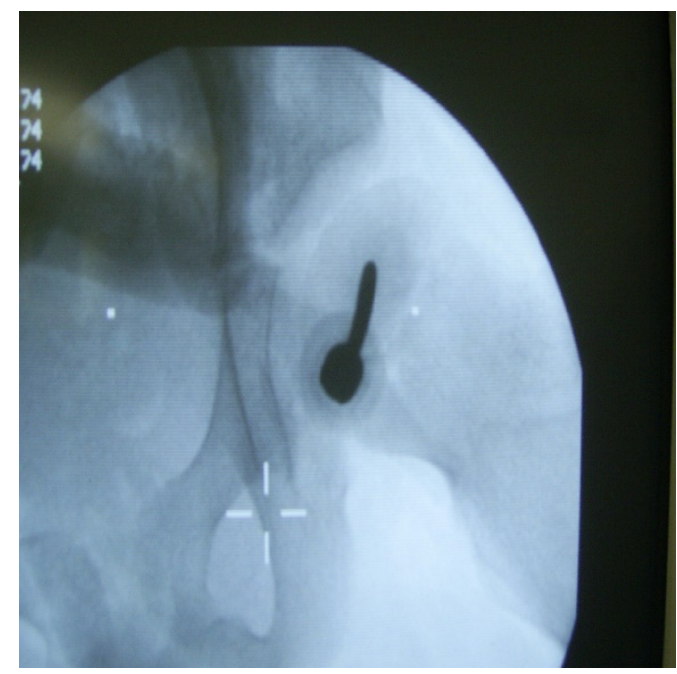

(c)

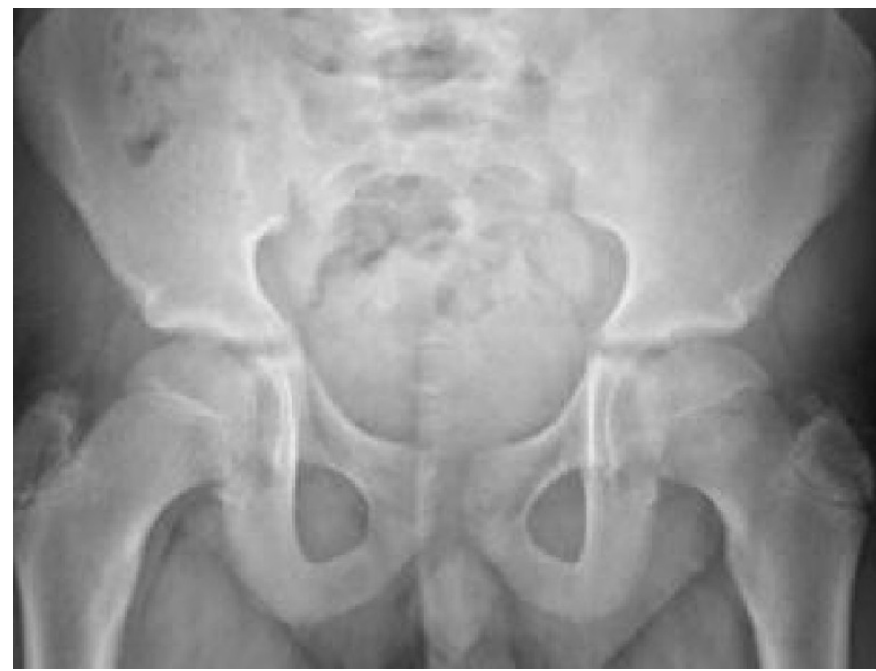

(e)

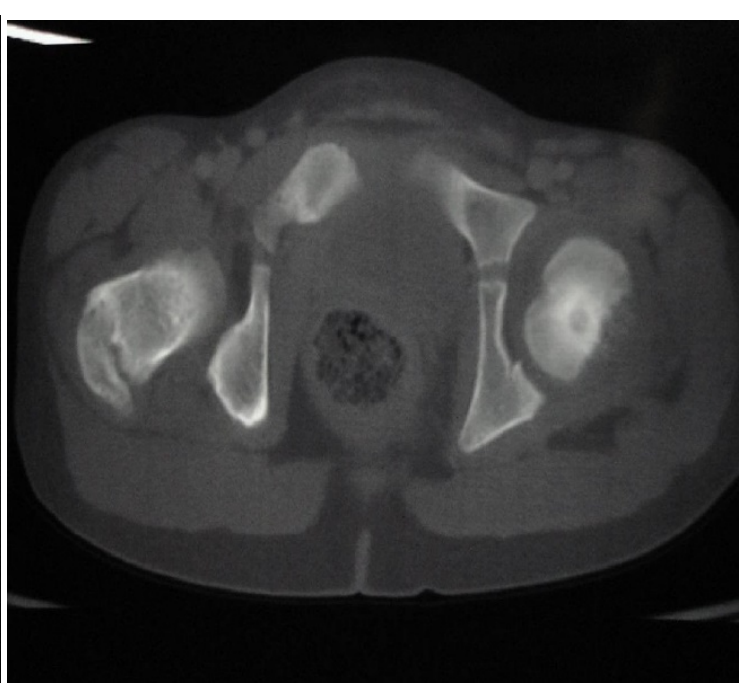

(b)

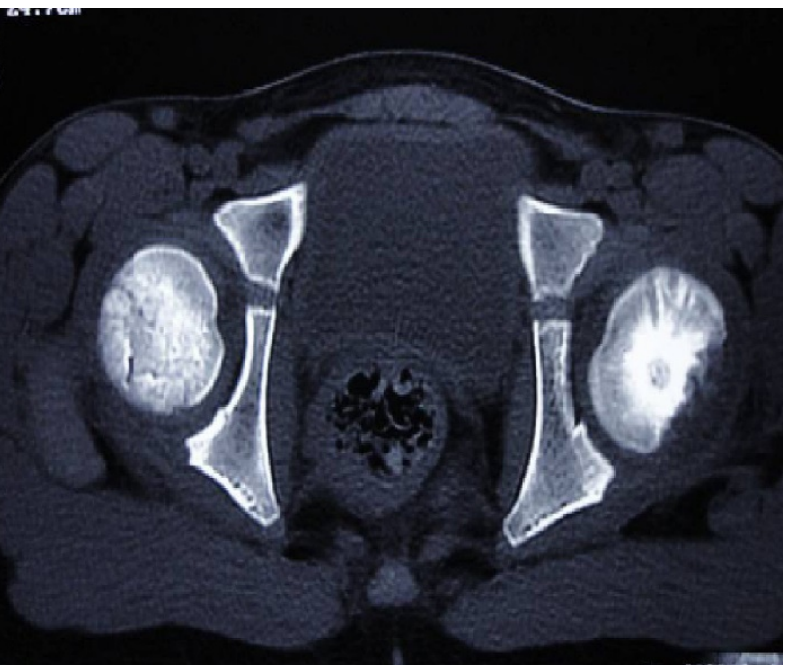

(d)

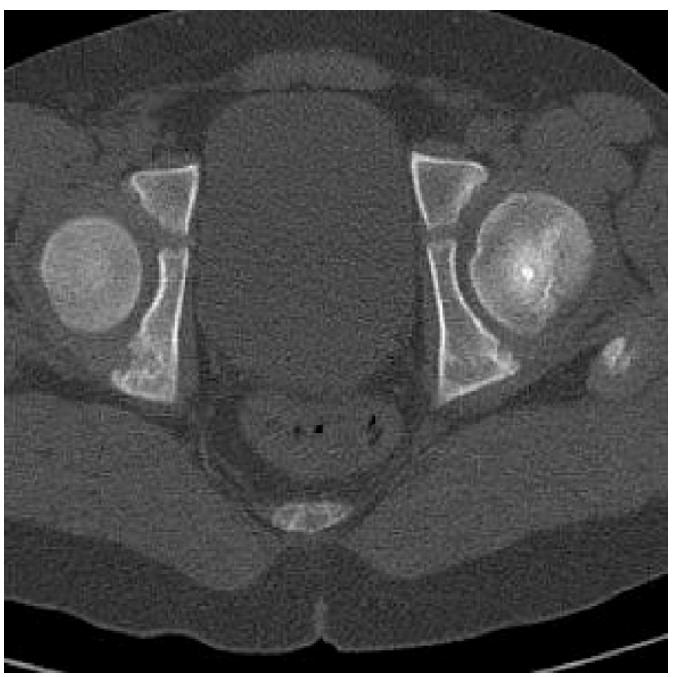

(f)

Figure 1. a) The $\mathrm{OO}$ of the capital femoral epiphysis with a sclerotic area together with a fairly delineated, centrally lucent focus b) $\mathrm{CT}$ scan of the $\mathrm{OO}$ of the capital femoral epiphysis, revealing a well-delineated sclerotic area with a central lytic focus c) Partial excision of the nidus using an 11G Jamshidi biopsy needle under fluoroscopy d) A CT image of the OO of the capital femoral epiphysis at the 1-year follow-up. The nidus began to calcify and dense sclerosis is evident e) An anteroposterior plain radiograph of the capital femoral epiphysis 72 months later. No significant findings were identified. The lucent focus has completely disappeared f) A CT image of the capital femoral epiphysis 72 months later. The nidus was completely calcified and the sclerotic rim had regressed in size and was mostly ossified 


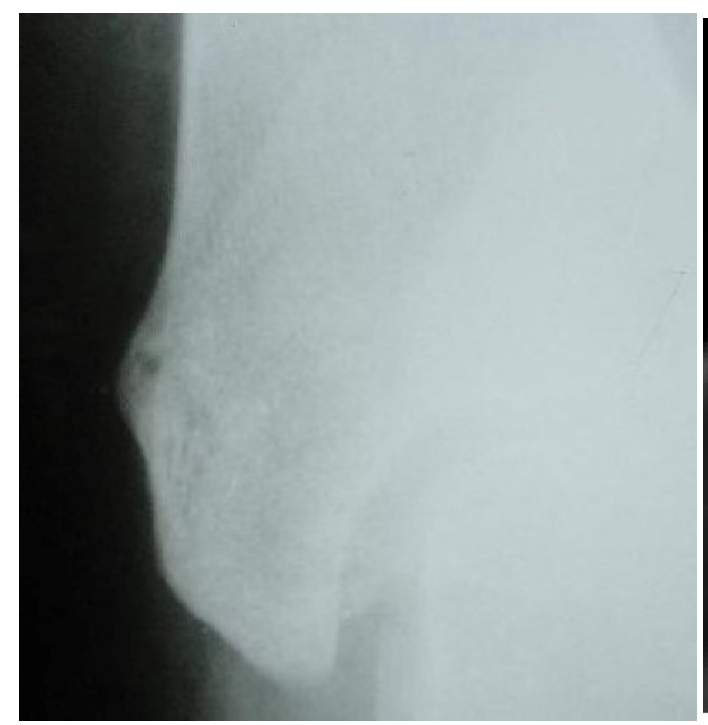

(a)

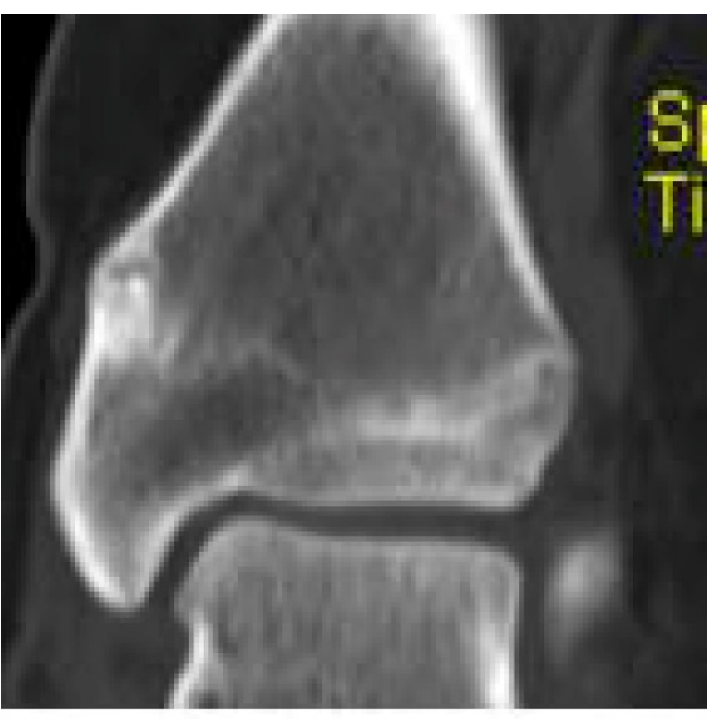

(b)

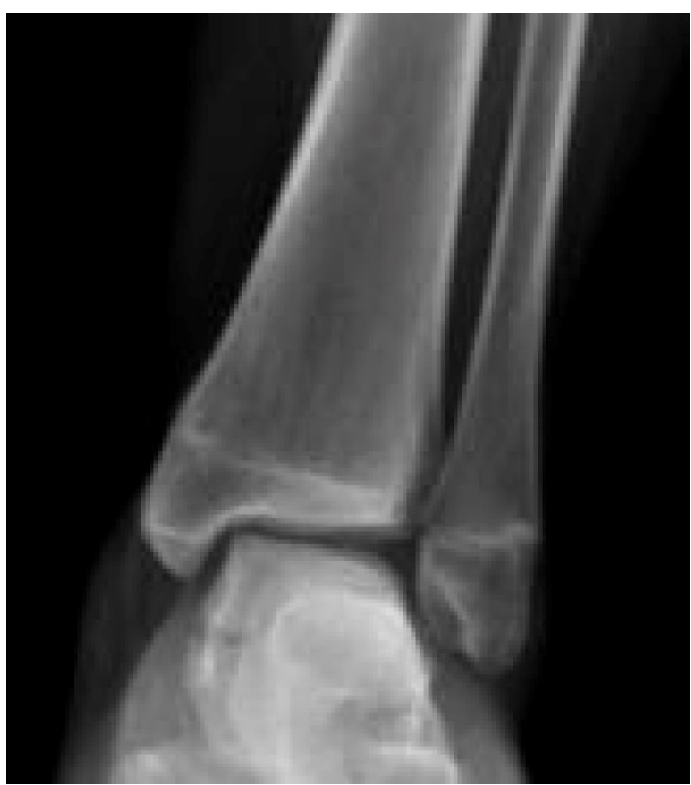

(c)

Figure 2. a) The atypical $O O$ of the left distal tibial epiphysis with a marginal lytic lesion and cortical thickening b) A coronal CT scan of the left distal tibia, revealing a marginal cortical bone defect with an eccentric dense bone reaction c) An anteroposterior plain radiograph of the left distal tibia showing the complete resolution of the 0032 months later

\section{Case 2}

Our second atypical 00 case was a 12-year-old boy with a 4 $\mathrm{mm}$ radiolucent lesion of the left distal epiphysis of the tibia, with cortical thickening on the medial side (Figure 2a). The lesion was located on the margin of the distal tibia and eccentric sclerosis was detected on CT imaging (Figure $\mathbf{2 b}$ ). An excision was performed by placing an 11G Jamshidi biopsy needle into the centrally located nidus under fluoroscopy. Histopathologic analysis confirmed the diagnosis. Follow-up plain radiographs showed a complete resolution of the 0032 months later (Figure $\mathbf{2 c}$ ), and no lesion was detected on CT.

\section{Case 3}

The third patient with an atypical 00 was a 18-year-old boy with a lesion located on the right proximal femur in the posterosuperior portion of the femoral neck. Plain pelvic radiographs revealed a mildly radiolucent lesion on the posterosuperior aspect of the femoral neck. A lytic lesion with peripheral sclerosis was seen on CT scan (Figure 3a). The size of the nidus was measured as $4 \mathrm{~mm}$. The same partial excision procedure as in the first two cases was performed. Histopathologic diagnosis confirmed an $\mathrm{OO}$. Plain radiographs taken at the 3-year follow-up were normal. The lucent area appeared calcified on CT (Figure 3b). 


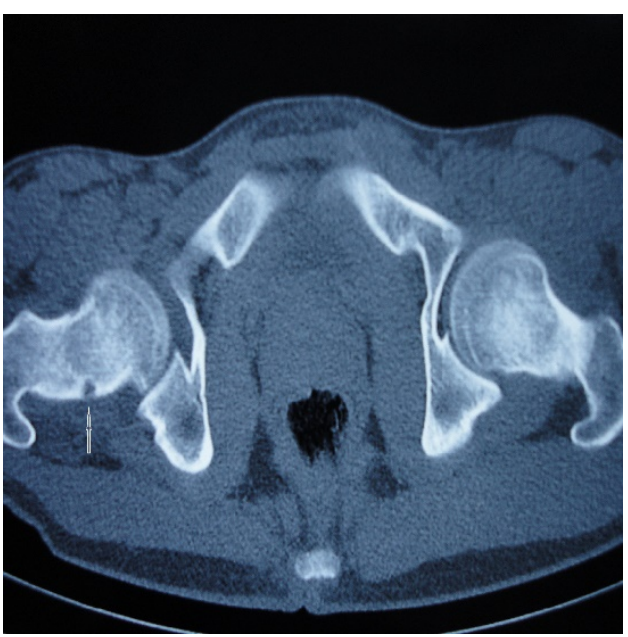

(a)

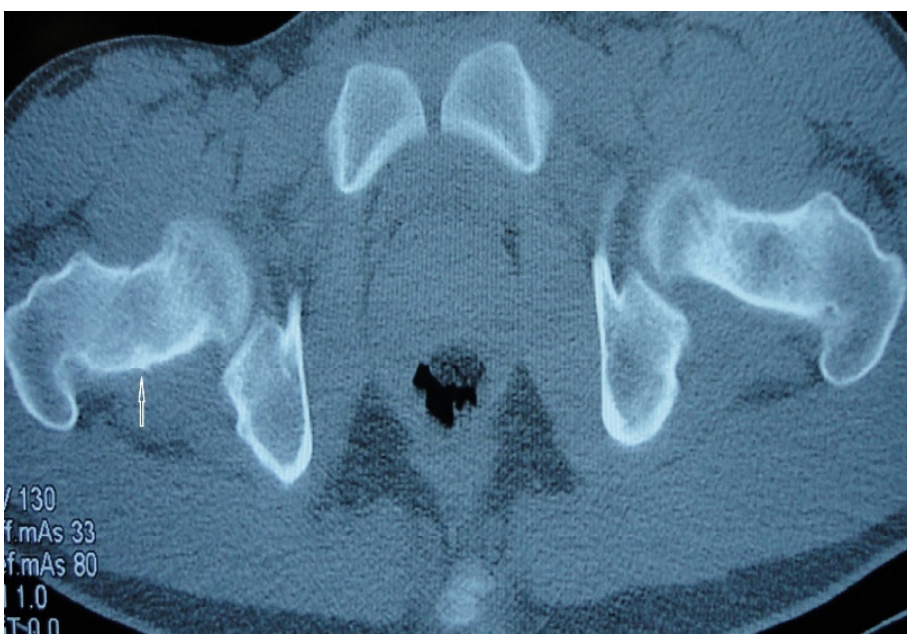

(b)

Figure 3. a) A transverse $C T$ scan of the hip showing a tiny radiolucent lesion in the posterosuperior of the femoral neck with marginal reactive sclerosis, illustrating an atypical case of $\mathrm{OO}$ b) A transverse pelvic CT scan of a patient with an OO located on the femoral neck that reveals the complete disappearance of the lesion 3 years later. The lytic lesion seems to be completely resolved with residual calcification

\section{Case 4}

The fourth case was a 21-year-old male patient with an atypical $\mathrm{OO}$ on the left olecranon process of the ulna. Plain radiographs showed a lucent area with a sclerotic rim inside the olecranon process, with an irregularity of the posterior cortex (Figure 4a). A CT scan of the lesion confirmed a welldelineated lytic area that was $3 \mathrm{~mm}$ in size, located lateral to the olecranon process. The lesion had a calcified focus and a mildly sclerotic rim (Figure 4b). The patient had followedup at another center for five months due to complaints of pain at the elbow, but had not been diagnosed with an $\mathrm{OO}$ during that period. The same treatment protocol was used on this patient. Histopathologic diagnosis confirmed the lesion as OO. Follow-up plain radiographs of the elbow showed a complete disappearance of the nidus 2 years later (Figure 4c).

\section{RESULTS}

In our patients, the average size of the $\mathrm{OO}$ nidus was $4 \mathrm{~mm}$ (range 3 to $5 \mathrm{~mm}$ ). The patient's pain resolved the night following excision of the nidus. No recurrence was observed at the $72,36,32$ and 24 month follow-ups.

\section{DISCUSSION}

Classical invasive surgical methods to treat an $\mathrm{OO}$ include en bloc resection and burr-down excision techniques. However, percutaneous radiofrequency ablation and percutaneous laser coagulation have become popular as minimally invasive techniques $[2,9,10,12]$. Other minimally invasive techniques include CT-guided excision $[13,14]$ and excision with arthroscopy [15]. Another method that was recently reported is the $\mathrm{MRI}$-guided focused ultrasound ablation technique [16]. However, this ablation method is not yet widely used. Resolution of pain is a good indicator of the success of surgery. The long-term resolution of pain following the partial excision of the $\mathrm{OO}$ was previously reported [17]. Some authors reported on clinically and radiographically diagnosed $\mathrm{OO}$ cases that spontaneously regressed within a matter of years $[11,18,19]$. It has been also been reported that the nidus first calcifies, then ossifies with a concurrent resolution of symptoms over time [20,21]. If the OO symptoms are mild and relieved by non-steroidal antiinflammatory drugs, clinical observation with follow-up is therefore the preferred approach.

An epiphyseal $\mathrm{OO}$ is extremely rare and has been reported in only a few cases in the literature $[5,8,9,22,23]$. The diagnosis of an epiphyseal $\mathrm{OO}$ is challenging and may present with similar radiographic findings to those of a chondroblastoma and a Brodie abscess [1]. A CT scan with contrast is preferable to differentiate these lesions from an OO. Legg Calve Perthes disease also has to be considered in cases without typical imaging findings [12]. Epiphyseal OOs may occur in or near intra-articular sites and may occasionally present with clinical findings ranging from joint effusion to decrease in range of movement. No similar findings were observed during the follow-up of our patients with an $\mathrm{OO}$ in the capital femoral epiphysis and the posterosuperior aspect of the femoral neck. An OO located in the tibial distal epiphysis [24] and the olecranon process of the ulna [25] is a rare pathology, whose diagnosis is often delayed due to insignificant symptoms and minimal radiographic findings during the onset of the disease. 


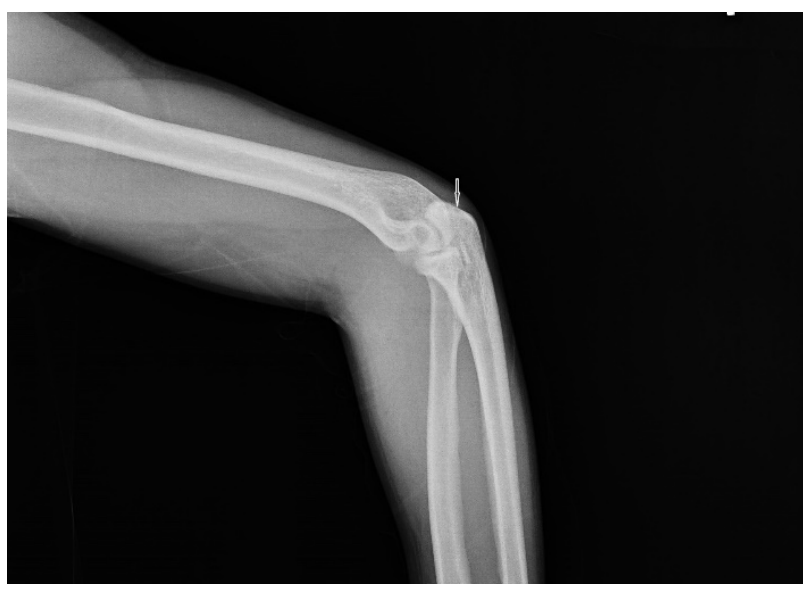

(a)

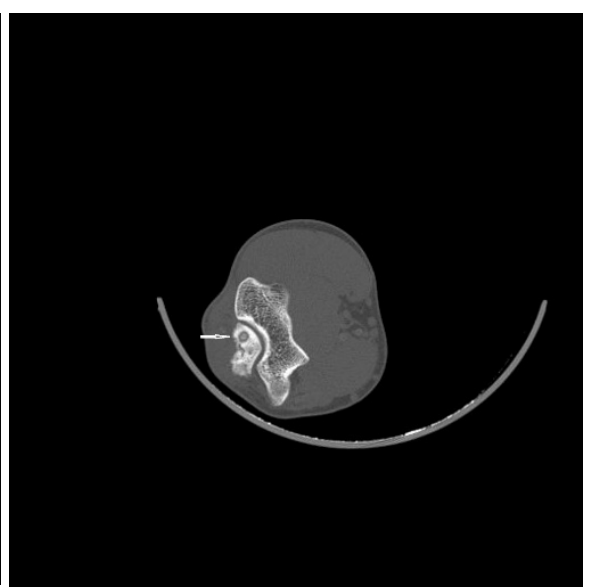

(b)

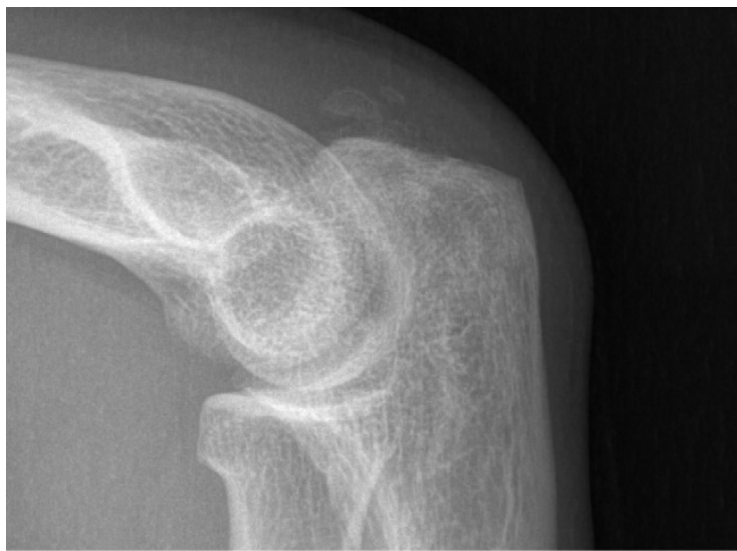

(c)

Figure 4. a) The lucent area with a mildly sclerotic rim of the olecranon process and an irregularity of the posterior cortex b) $A$ CT image showing a well-delineated lytic area with a calcified focus on the radial side of the olecranon process c) A lateral plain radiograph of the elbow 2 years later. The nidus has completely disappeared. Soft tissue calcification on the posterior aspect of the elbow

The limited number of patients and enrolling only patients with atypically located cancellous osteoid osteoma constitute limitations of our study. We do not assert that the technique we propose, performed on a limited number of patients, will be an immediate alternative to the current successful methods [2,9] exhibited in the literature. However, taking the positive outcomes achieved in all patients following partial excision of the nidus into account, we concluded that the technique may be applied on atypical cancellous osteoid osteoma cases, surgically challenging and open to complications as in the osteoid osteoma of the femoral epiphysis in pediatric patients. Our results on the posterosuperior femoral neck, distal epiphysis of the tibia and olecranon process of the ulna, where a surgical intervention is relatively easier, is encouraging for performing partial excision of the nidus. The technique we utilized in the treatment of OOs is different from its predecessors, which advocate complete excision or destruction of the nidus. The technique also differs from the burr-down excision technique. Complete excision of a nidus with a diameter of 3 to $5 \mathrm{~mm}$ is geometrically impossible by two sequential punches of the $11 \mathrm{G}$ bone marrow biopsy needle. We therefore preferred a partial excision of the nidus. By performing the partial excision technique twice in the nidus of the same lesion, we aimed to increase our chances of excising a significant amount of material from the nidus.

In conclusion, partial excision of the nidus using a bone marrow biopsy needle is an efficient and easily applicable technique. With the minimally invasive technique we propose, partial excision of the nidus may be considered a remarkable alternative in the treatment of atypical cancellous osteoid osteoma where surgical intervention is challenging and complications may be encountered. Further studies enrolling large population of patients are warranted for validation of our technique.

\section{DECLARATION OF CONFLICT OF INTEREST}

The authors received no financial support for the research and/or authorship of this article. There is no conflict of interest. 


\section{REFERENCES}

1. Edeiken J. Rontgen diagnosis of diseases of bone. London: Williams \& Wilkins; 1981.

2. Bourgault C, Vervoort T, Szymanski C, Chastanet P, Maynou C. Percutaneous CT-guided radiofrequency thermocoagulation in the treatment of osteoid osteoma: A 87 patient series. Orthop Traumatol Surg Res 2014;100:323-7.

3. Unni KK, Inwards CY. Dahlin's Bone Tumors: General Aspects and Data on 10,165 Cases. Philadelphia: Lippincott Williams and Wilkins; 2010.

4. Yildiz Y, Bayrakci K, Altay M, Saglik Y. Osteoid osteoma: the results of surgical treatment. Int Orthop 2001;25:119-22.

5. Brody JM, Brower AC, Shannon FB. An unusual epiphyseal osteoid osteoma. AJR 1992;158:609-11.

6. Kalem M, Şahin E, Kocaoğlu H, Başarır K, Yıldız Y, Sağlık, Y. Osteold osteoma: bir ayak ağrısı nedeni. Ortadoğu Tıp Dergisi 2018;10:179-82.

7. Lisanti M, Rosati M, Spagnolli G, Luppichini G. Osteoid osteoma of the carpus. Case reports and a review of the literature. Acta Orthop Belg 1996;62:195-99.

8. Mahata KM, Keshava SK, Jacob KM. Osteoid osteoma of the femoral head treated by radiofrequency ablation: a case report. J Med Case Rep 2011;5:115.

9. Papathanassiou ZG, Petsas T, Papachristou D, Megas P. Radiofrequency ablation of osteoid osteomas: five years experience. Acta Orthop Belg 2011;77:827-33.

10. Shinozaki T, Sato J, Watanabe H, et al. Osteoid osteoma treated with computed tomography-guided percutaneous radiofrequency ablation: a case series. J Orthop Surg 2005;13:317-22.

11. Jaffe $\mathrm{HL}$ Osteoid osteoma. Proc $\mathrm{R}$ Soc Med 1953;46:1007-12.

12. Ciftdemir M, Tuncel SA, Usta U. Atypical osteoid osteoma. Eur J Orthop Surg Traumatol 2015;25:17-27.

13. Assoun J, Railhac JJ, Bonnevialle P, et al. Osteoid osteoma: percutaneous resection with $\mathrm{CT}$ guidance. Radiology 1993;188:541-7.
14. Raux S, Kohler R, Canterino I, Cholet F, Abelin-genevois K. Osteoid osteoma of acetabular fossa: five cases treated with percutaneous resection. Orthop traumatol Surg Res 2013;99:341-46.

15. Khapchik V, O'Donnell RJ, Glick JM. Arhroscopically assisted excision of osteoid osteoma involving the hip. Artroscopy 2001;17:56-61.

16. Geiger D, Napoli A, Conchiglia A, et al. MR-guided focused ultrasound (MRgFUS) ablation for the treatment of nonspinal osteoid osteoma: a prospective multicenter evaluation. J Bone Joint Surg Am 2014;96:743-51.

17. Norman A. Persistence or recurrence of pain: a sign of surgical failure is osteoid-osteoma. Clin Orthop Relat Res 1978;130:263-66.

18. Kneisl JS, Simon MA. Medical management compared with operative treatment for osteoid osteoma. J Bone Joint Surg Am 1992;74:179-85.

19. Moberg E. The natural course of osteoid osteoma. J Bone Joint Surg Am 1951;33:166-70.

20. Lee EH, Shafi M, Hui JHP. Osteoid osteoma: a current review. Journal of Pediatric Orthopaedics 2006;26:695-700.

21. Nielsan GP, Rosenberg AE. Bone forming tumors. In: Folpe $A L$, Inwards $C Y$ (eds). Bone and soft tissue pathology. A volume in the series foundations in diagnostic pathology, 1st ed. Philadelphia: Sounders. 2010:309-29.

22. Sibenrock KA, Asencio J, Ganz R, Poal-Manresa J. Osteoid osteoma in the femoral head -a report of 3 cases. Acta Orthop Scand 1997;68:70-6.

23. Van Horn JR, Karthaus RP. Epiphyseal osteoid osteoma. Two case reports. Acta Orthop Scand 1989;60:625-7.

24. Simon WH, Beller ML. Instrcapsular epiphyseal osteoid osteoma of ankle joint. A case report. Clin Orthop Relat Res 1975;108:200-3.

25. Dzupa V, Bartonícek J, Sprindrich J, Neuwirth J, Svec A. Osteoid osteoma of olecranon process of ulna in subchondral location. Arch Orthop Trauma Surg 2001;121:117-8. 